(C) М. I. Магац, к.т.н., 3. О. Гошко, к.т.н.

Львівський національний аграрний університет

С. В. Синій, к.т.н.

Луцький національний технічний університет

\title{
МІНІ-АГРЕГАТ ДЛЯ ВИКОПУВАННЯ КАРТОПЛІ
}

У статті описано процес роботи модернізованого мініагрегату «мотоблок + лапа-викопувач» для збирання коренебульбоплодів. Наведено результати проведених порівняльних експериментальних (польових) досліджень, на основі яких доведено його здатність здійснювати викопування картоплі на забур'янених трунтах з показниками роботи, кращими за показники базового міні-агрегату.

МІНІ-АГРЕГАТ ДЛЯ ЗБИРАННЯ КОРЕНЕБУЛЬБОПЛОДІВ, ЛАПА-ВИКОПУВАЧ 3 ВІДКРИЛКАМИ, МОТОБЛОК «ЗУБР», ВИТРАТА ПАЛИВА, ЧАС РОБОТИ

Постановка проблеми. Широкого застосування в групі мобільних енергетичних засобів для невеликих фермерських та присадибних господарств набули міні-агрегати (енергетичні засоби 3 колісною формулою 2К2) та міні-трактори, загальна кількість яких у вітчизняних дрібних господарствах стрімко зростає і на сьогодні досягла понад 150 тис. штук [1-4 та ін.].

Така міні-техніка не завжди забезпечує якісний результат у сенсі вимог до ії використання (через конструктивні, експлуатаційні та технологічні причини), що можна пояснити недоліками конструкцій, відсутності необхідного спектру технологічних модулів для агрегатування та відсутності навиків у налагодженні агрегатів [3].

Зважаючи на близькість та/або подібність фізикомеханічних та розмірно-масових показників більшості з поширених в Україні сортів корене- та бульбоплодів, робочі органи для їх викопування мають подібну форму і розміри. А тому, у дрібних господарствах для викопування коренебульбоплодів часто використовують універсальні копачі, Така практика особливо поширена серед знарядь для міні-агрегатів.

Недостатнє пристосування відомих конструкцій копачів коренебульбоплодів до значного варіювання реальних агротехнічних умов збирання не забезпечує надійне виконання 
копачем операцій викопування та початкової сепарації, а це призводить до збільшення втрат коренебульбоплодів [4-9 та ін.].

Зокрема, при екстремальних умовах збирання картоплі лапами-викопувачами на забур'янених ділянках збільшуються втрати незібраної картоплі, яка була залишена у грунті.

Зважаючи на викладене вище, до актуальних питань ефективної роботи міні-агрегатів потужністю до 6,3 кВт слід віднести розробку їх удосконалених конструкцій, які б забезпечували задані виробничі умови агрегатування копачів коренебульбоплодів, зокрема для вирішення проблем їх маневреності в обмежених умовах невеликих ділянок, незадовільного викопування коренебульбоплодів на забур'янених ділянках.

Аналіз останніх досліджень і публікацій. У зв'язку 3 великим попитом на вітчизняному ринку техніки на міні-агрегати для обробітку грунту та збору коренебульбоплодів (на невеликих ділянках), на сьогодні спостерігається широке використання мініагрегатів вітчизняного i закордонного виробництва потужністю 0,7...6,3 кВт і масою 30...300 кг [1-3 та ін.].

За витратами на збирання картоплі (грн./га) міні-агрегати ефективно використовувати у дрібних господарствах, на площах до 2 га [9].

Проведений аналіз літературних джерел [3, 4, 9-16 та ін.] показав, що стосовно вимог експлуатації, до найбільш поширених напрямків дослідження малогабаритних енергетичних засобів 3 колісною формулою 2 К2, задіяних в операціях обробітку грунту та збирання коренебульбоплодів міні-агрегатами, можна віднести: вдосконалення конструкції мотоблоків; покращення керування та ергономічних показників експлуатації мотоблоків зокрема та мініагрегатів загалом; підвищення стабільності і стійкості роботи мініагрегатів; вивчення способів покращення експлуатаційних показників. При цьому, серед найпоширеніших важливих завдань таких досліджень $є$ : досягнення зниження ущільнення грунту; покращення технічних характеристик трансмісії міні-агрегатів; зниження шкідливого впливу вібрації міні-агрегатів на людину, зменшення зусиль на їх керування; підвищення стійкості ходу мініагрегатів при виконанні операцій (оранка, культивація, фрезерування, викопування коренебульбоплодів та ін.) [3].

Проблема використання міні-агрегатів для збирання коренебульбоплодів на присадибних ділянках (у важкодоступних місцях, 3 обмеженою маневреністю) $є$ особливо актуальною для вітчизняного виробництва картоплі. Адже, загальновідома 
багаторічна вітчизняна статистика свідчить, що близько $95 \%$ картоплі виробляється дрібними виробниками - переважно населенням на присадибних ділянках, а також селянськими та фермерськими господарствами.

Зазвичай, на присадибних ділянках та у більшості селянських господарств використовують прості знаряддя праці та засоби механізації, а в останні роки - стрімко зростає використання доступних за ціною міні-агрегатів. Основними ж причинами застосування міні-агрегатів дрібними фермерськими господарствами $є$ потреба в обробітку малих та/або важкодоступних ділянок.

Слід зауважити, що сучасні умови виробництва картоплі дрібними виробниками (в Україні та в технічно розвинених, в більшій чи меншій мірі, країнах світу) формують тенденції розвитку універсальності застосування малогабаритних енергетичних засобів, які зумовлюються економічною та технічною доцільністю подальшого розширення модельного ряду мініагрегатів для різних польових операцій виробництва картоплі 3 метою збільшення ефективності їх застосування. Ці тенденції відповідно впливають на темпи і ефективність розвитку процесів ресурсного забезпечення технологій виробництва картоплі та рослинництва загалом. При цьому, синергія досліджень умов агрегатування мотоблоків і режимів їх роботи $є$ визначальною для забезпечення ефективності застосування міні-агрегатів в операціях виробництва картоплі. Адже, як зазначається у [3 та ін.], показники ефективності роботи міні-агрегатів формуються в системі «людинамашина», оскільки людина не лише управляє міні-агрегатом, але й керує ним своєю мускульною силою.

Проведений аналіз літературних джерел та ряду інтернетресурсів [1-3 та ін.] свідчить, що у присадибних господарствах значна кількість робіт виконується агрегатами:

- мотоблок «Бізон» 900 Lux + лапа-викопувач;

- мотоблок «Кентавр» МБ40-2 + лапа-викопувач;

- мотоблок «Sadko» M-1165 + лапа-викопувач;

- мотоблок «Kipor» KDT610Е + лапа-викопувач;

- мотоблок «Зубр» НТ-105 + лапа-викопувач.

На основі проведеного аналізу конструкцій вищевказаних міні-агрегатів, встановлено, що всі вони укомплектовані однаковими за конструктивними ознаками підкопувальними лапами, недоліком яких $\epsilon$ неякісне підкопування коренебульбоплодів, особливо при надмірній забур'яненості поля та підвищеній вологості грунту. 
Дослідженнями, наведеними у $[3,4, \quad 9-16$ та ін.] підтверджено, що існуючі копачі для міні-агрегатів далекі від ідеалу і потребують вдосконалень.

Аналіз роботи існуючих лап-викопувачів (які практично одночасно виконують дві технологічні операції - викопування та початкову сепарацію вороху) показав, що об’єктивною причиною їх недосконалості $є$ відсутність можливості регулювання конструктивних параметрів копача.

Модернізація конструкцій копачів повинна базуватись на основах системного підходу, що враховує вплив фізико-механічних властивостей грунтів, а також особливостей експлуатації збиральної техніки [5-9].

Мета дослідження - підвищення техніко-економічних показників міні-агрегату «мотоблок + лапа-викопувач» при викопуванні картоплі за рахунок модернізації конструкції картоплекопача.

Результати дослідження. Дослідним шляхом було встановлено, що найбільш придатний за своїми технічними характеристиками для викопування картоплі в західному регіоні України (переважна більшість грунтів супіски та суглинки) є мініагрегат: «Зубр» НТ-105 + картоплекопач (лапа-викопувач). Тому такий міні-агрегат було взято за базовий для проведення польових досліджень.

У картоплезбиральній техніці функціональне призначення копача картоплі полягає в тому, щоб розбити (розкрити, подрібнити) гребінь грунту, з якого бульби картоплі витиснути вгору i направити на робочі органи початкової сепарації бульбовмісного шару грунту. Далі, залежно від складності конструкції збиральної техніки, залишити задовільно очищені бульби на поверхні грунту для зручності збирання або перенаправити на наступні робочі органи для завершення сепарації вороху картоплі.

Конструктивно, з метою підвищення техніко-економічних показників досліджуваного міні-агрегату 3 лапою-викопувачем, пропонується додатково встановити регулювальний механізм для корекції кута піднімання і перекидання грунту. Даний механізм при виконанні операції кришення грунту сприяє підвищенню показників основного процесу сепарації картоплі - подрібнення грунту, для кращого просипання його крізь відкрилки лапивикопувача.

У процесі викопування картоплі базовим агрегатом («Зубр» НТ-105 + лапа-викопувач), спостерігаються значні втрати 
невикопаних бульб (до 7 \%). Цей факт пояснюється встановленням лапи-викопувача на рамі міні-агрегату 3 фіксованим кутом входження в грунт, що $\epsilon$ причиною надмірного кута піднімання грунту та забиванням iї відкрилків. Як наслідок, це погіршує відділення картоплі від грунту та ії очищення.

Для вирішення даної проблеми пропонується застосувати модернізовану лапу, обладнану регулювальним механізмом, який розміщується в задній iї частині [4], кінематика роботи та конструктивне рішення модернізованого міні-агрегату наведені на рис. 1.
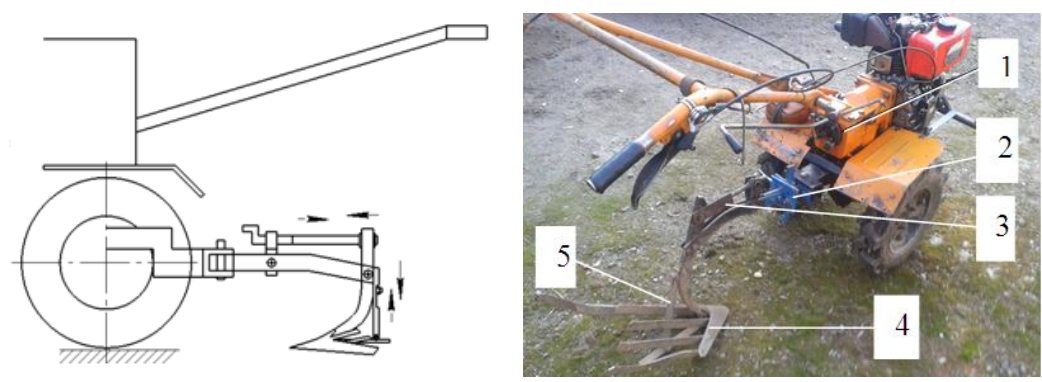

Рис. 1 - Схема і загальний вигляд модернізованого міні-агрегату для викопування картоплі: 1 - мотоблок «Зубр»; 2 - зчіпка; 3 - механізм регулювання кута входження; 4 - лапавикопувач з відкрилками; 5 - механізм регулювання стабілізації ходу.

Для проведення польових досліджень використали мотоблок «Зубр» НТ-105 масою 120 кг.

Робота модернізованого копача полягає в наступному. Встановлена на рамі зчіпки лапа-викопувач 4 підкопує та піднімає шар грунту з бульбами картоплі під певним регульованим кутом, а на іiі відкрилках проходить сепарація грунту (подрібнення та просівання), що сприяє переміщенню бульб картоплі на поверхню поля.

Робота регулятора кута підйому відкрилок лапи дозволяє краще перекидати грунт та розкривати бульби картоплі на поверхні поля (особливо, коли поле характеризується надмірною забур'яненістю або підвищеною вологістю грунту).

Регулювання лапи реалізується у двох технічних рішеннях, які забезпечують: 


\section{Сільськогосподарські машини. Випуск 43}

- можливість зміни кута нахилу лапи-викопувача за ходом агрегату (від $10^{\circ}$ до $35^{\circ}$ ), що забезпечує краще розкривання i переміщення картоплі на поверхню поля (рис. 2);

- можливість стабілізації ходу лапи-викопувача, що дозволяє регулювати глибину підрізання пласта грунту у горизонтальній площині.

Як видно зі схеми на рис. 2.а, лапа-викопувач 23 регулятором ходу 1 забезпечує краще розкривання і сепарацію їі на відкрилках пласта грунту 4 з бульбами картоплі 3, у порівнянні 3 роботою за схемою на рис. 2.6 стандартної лапи-викопувача 3 постійним рівнем підкопаного пласта грунту 5.

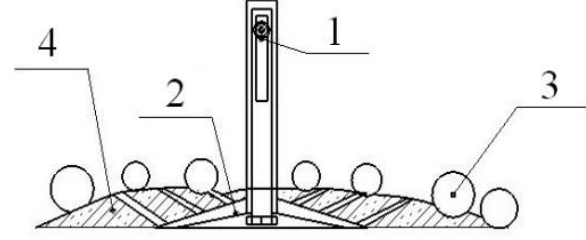

a)

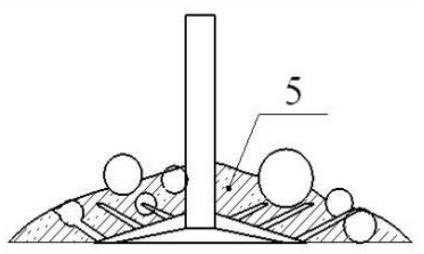

б)

Рис. 2 - Схема роботи лапи-викопувача: а) - модернізована лапавикопувач 2 з регулятором ходу 1; б) - стандартна лапа-викопувач; 4, 5 - пласти грунту при сепарації з бульбами картоплі 3 в/на них.

Проведення експериментальних досліджень передбачало визначення якості викопування бульб картоплі, витрату палива та маневреність модернізованого міні-агрегату «Зубр» НТ-105 + лапавикопувач.

Об'єктом досліджень був вищезазначений агрегат 3 встановленим регулювальним механізмом ходу на лапі-викопувачі.

Цьогорічні дослідження проводили на двох дослідних ділянках площею по 500 м² (перша - відсутня забур'яненість, друга - забур'янена). 
Узагальнені результати польових досліджень, які також включають експериментальні дані [4], зведені у наведену нижче таблицю.

Аналіз даних таблиці дає змогу встановити відмінність між показниками роботи базового і модернізованого робочих органів, зокрема відносно роботи базового обладнання:

- час викопування картоплі зменшився на експериментальній ділянці на 0,3 год, або на 27,3\%;

- витрата палива зменшилась на 0,1-0,2 л (на ділянках площею $500 \mathrm{M}^{2}$ ), або на 16,7-28,6 \%;

- опір модернізованої лапи-підкопувача зменшився на 0,05 0,2 кН, або на 4,0-17,4 \%;

Таблиця - Результати порівняльних експериментальних досліджень міні-агрегату «Зубр» НТ-105 + лапа-викопувач

\begin{tabular}{|c|c|c|c|c|}
\hline \multirow{2}{*}{ Показники } & \multicolumn{3}{|c|}{$\begin{array}{c}\text { Результати досліджень, для } \\
\text { варіантів міні-агрегату: }\end{array}$} & \multirow{2}{*}{$\begin{array}{c}\text { Різниця } \\
\text { виміряних } \\
\text { показників }\end{array}$} \\
\hline & \multicolumn{2}{|c|}{ базовий } & $\begin{array}{l}\text { модернізо- } \\
\text { ваний }\end{array}$ & \\
\hline Maca, кг & \multicolumn{2}{|c|}{120} & 120 & 0 \\
\hline $\begin{array}{l}\text { Робочий час } \\
\text { агрегату, год }\end{array}$ & \multirow{3}{*}{ 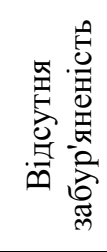 } & 1,1 & 0,8 & 0,3 \\
\hline $\begin{array}{l}\text { Витрата палива } \\
\text { на } 500 \mathrm{~m}^{2}, \text { л }\end{array}$ & & 0,6 & 0,5 & 0,1 \\
\hline Опір лапи, кН & & $\begin{array}{c}1,1 \\
5\end{array}$ & 0,95 & 0,2 \\
\hline $\begin{array}{l}\text { Робочий час } \\
\text { агрегату, год. }\end{array}$ & \multirow{3}{*}{ 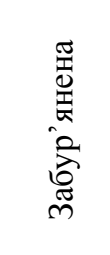 } & 1,4 & 1,1 & 0,3 \\
\hline $\begin{array}{l}\text { Витрата палива } \\
\text { на } 500 \mathrm{~m}^{2}, \text { л }\end{array}$ & & 0,7 & 0,5 & 0,2 \\
\hline Опір лапи, кН & & $\begin{array}{c}1,2 \\
5\end{array}$ & 1,20 & 0,05 \\
\hline
\end{tabular}

Висновки. Продуктивність модернізованого міні-агрегату «Зубр» НТ-105 + лапа-викопувач зросла з $455 \mathrm{~m}^{2}$ до $625 \mathrm{~m}^{2}$ за 1 год (для незабур'яненого поля), а для частково забур'яненого поля продуктивність зросла з $357 \mathrm{~m}^{2}$ до $454 \mathrm{~m}^{2}$ за 1 год.

Також, завдяки встановленню модернізованої лапи зросла маневреність міні-агрегату, а витрата палива зменшилась до 0,5 л на 
$500 \mathrm{~m}^{2}$, що на 16,7-28,6 \% менше порівняно $з$ базовим варіантом агрегату.

\section{Література}

1. Мотоблоки Зубр [Електронний ресурс]. - Режим доступу: www.olx.ua/uk/list/q-мотоблок-зубp/

2. Картоплекопалки для мотоблоків [Електронний ресурс]. Режим доступу: https://moimotoblok.com.ua/navesnoe-k-motoblokam/

3. Магац М. І. Експлуатаційні дослідження модернізованого міні-агрегату / М. І. Магац, Т. А. Махоркіна, 3. О. Гошко, А. В. Дусан, С. В. Синій // Сільськогосподарські машини: Зб. наук. ст. - Луцьк, 2018 - Вип. 39. - С. 93-100.

4. Магац М. И. Результаты исследований модернизированного мини-агрегата для уборки картофеля / М. И. Магац, 3. О. Гошко, С. В. Синий // Новые материалы, оборудование и технологии в промышленности: материалы Междунар. науч.-техн. конф. молод. ученых - Могилев: Белорус.-Рос. ун-т, 2019. - С. 56.

5. Налобіна О. О. Системний аналіз підкопуючих робочих органів картоплезбиральних машин / О. О. Налобіна, М. Г. Грушецька, А. В. Шимко // Сільськогосподарські машини: Зб. наук. ст. - Луцьк, 2015 - Вип. 32. - С. 134-138.

6. Hevko R. B. Development of design and investigation of operation processes of small-sclale root crop and potato harvesters / R. B. Hevko, I. G. Tkachenko, S. V. Synii, I. V. Flonts // INMATEH - Agricultural Engineering. - Bucharest: INMA Bucharest, 2016. - Vol. 49. -Nr. 2. pp. 53-60.

7. Baranovsky V.M. Chicory root crops combined harvester / V.M. Baranovsky, O.Ju. Skalsky, M.R. Pankiv, A.S. Pastushenko // INMATEH - Agricultural Engineering. - Bucharest: INMA Bucharest, 2017. - Vol. 53, Nr. 3. - pp. 41-50.

8. Dumitru I., Voicea I., Găgeanu I. ect. Technical considerations regarding to harvesting patatoes and carrots equipment // Annals of the University of Craiova - Agriculture, Montanology, Cadastre Series. Craiova (Romania), 2017, Vol 47, No 2 - pp. 317-323.

9. Жаріков А. Аналіз конструкцій технічних засобів для збирання картоплі / А. Жаріков // Техніко-технологічні аспекти розвитку та випробування нової техніки і технологій для сільського господарства України. - 2013. - Вип. 17(1). - С. 353-360.

10. Артьомов М.П. Математична модель машино-тракторного агрегату 3 використанням методу парціальних прискорень / М.П. Артьомов // Зб. наук. пр. ВНАУ. - 2012.-Вип.11, Т.1(65).-С.3440. 
11. Довідник сільського інженера / В. Д. Гречкосій, О. М. Погорілець, І. І. Ревенко та ін. - К. : Урожай, 1991. - 400 с.

12. Погорілий Л. В. Мобільна сільськогосподарська енергетика: історія, тенденції розвитку, прогноз / Л. В. Погорілий, В. Г. Євтенко. -К.: Фенікс, 2005. - 184 с.

13. Ріпка I. І. Основи механізації і автоматизації сільськогосподарського виробництва, навч. посібник / І. І. Ріпка, Я. В. Семен. - 2ге вид., переробл. і доповн. - Львів: ЛНАУ, 2008. - 174 с.

14. Шевчук Р. С. Теорія, основи розрахунку і аналіз роботи тракторів та автомобілів: мет. реком. / Р. С. Шевчук. - Львів: ЛДАУ, 2001. $-50 \mathrm{c}$.

15. Скойбеда А. Т. Колесно-шагающие движители для транспортного средства высокой проходимости / А. Т. Скойбеда, В. Н. Жуковец // Теоретическая и прикладная механика: междунар. науч.-техн. сборник БНТУ. - Минск, 2013. - Вып. 28. - С. 228-233.

16. Подрубалов М. В. Совершенствование виброзащиты оператора транспортного мотоблока в системе малой механизации лесохозяйственной и лесопарковой деятельности: автореф. дисс. канд. техн. наук 05.21.01 / М. В. Подрубалов. - М., 2012. - 18 с. 